\title{
Eruptive lichen planus in a six-year-old boy
}

\author{
Liszaj płaski wysiewny u sześcioletniego chłopca
}

Paulina Szczepanik-Kułak, Joanna Bartosińska, Bartłomiej Wawrzycki, Dorota Krasowska

Department of Dermatology, Venereology and Pediatric Dermatology, Medical University of Lublin, Poland

Katedra i Klinika Dermatologii, Wenerologii i Dermatologii Dziecięcej Uniwersytetu Medycznego w Lublinie, Polska

Dermatol Rev/Przegl Dermatol 2019, 106, 310-320

DOI: https://doi.org/10.51|4/dr.2019.869|4

\author{
CORRESPONDING AUTHOR/ \\ ADRES DO KORESPONDENCJI: \\ lek. Paulina Szczepanik-Kułak \\ Katedra i Klinika \\ Dermatologii, Wenerologii \\ i Dermatologii Dziecięcej \\ Uniwersytet Medyczny \\ ul. Staszica 16 \\ 20-081 Lublin \\ tel.: +48 889987497 \\ e-mail: vpaulinav@gmail.com
}

\begin{abstract}
Introduction. Lichen planus is rarely encountered in children, with less than $2-3 \%$ of all cases. Variants, response to the treatment and prognosis are almost the same in both children and adult patients. Early diagnosis as well as proper treatment shorten the duration of time and improve the quality of life.
\end{abstract}

Objective. To present a case of a six-year-old boy diagnosed with eruptive lichen planus.

Case report. A six-year-old boy was hospitalised because of eruptive form of lichen planus. Treatment with systemic glucocorticosteroids, antihistamines, hydrocortisone, mometasone ointment and narrowband UVB phototherapy resulted in a fast clinical improvement.

Conclusions. This case indicates that the diagnosis of lichen planus has to be taken under consideration in cases of pruritic papules in children. In this case systemic medication was required because of the severe course of disease.

\section{STRESZCZENIE}

Wprowadzenie. Liszaj płaski to zapalna dermatoza mediowana immunologicznie. Rzadko występuje u dzieci, jedynie w 2-3\% wszystkich rozpoznanych przypadków. Chorobie może towarzyszyć świąd o znacznym nasileniu. Postacie kliniczne, odpowiedź na zastosowane leczenie oraz rokowanie nie różnią się znacząco u dzieci i osób dorosłych. Wczesne rozpoznanie i odpowiednie leczenie skracają czas trwania choroby i wpływają na poprawę jakości życia pacjentów.

Cel pracy. Opis przypadku sześcioletniego chłopca z rozpoznaniem odmiany wysiewnej liszaja płaskiego oraz dyskusja na temat tej rzadko występującej u dzieci dermatozy.

Opis przypadku. Sześcioletni chłopiec został przyjęty do Kliniki Dermatologii, Wenerologii i Dermatologii Dziecięcej w Lublinie z powodu stopniowo pojawiających się i utrzymujących od około miesiąca wykwitów grudkowych, którym towarzyszył intensywny świąd, przyczyniający się do zaburzeń snu i pogarszający codzienne funkcjonowanie. $\mathrm{Na}$ podstawie obrazu klinicznego oraz wyniku badania histopatologicznego rozpoznano odmianę wysiewną liszaja płaskiego. W wyniku zastosowanego leczenia - ogólnej glikokortykosteroidoterapii, leków przeciwhistaminowych, hydrokortyzonu i mometazonu w maści oraz 
fototerapii UVB 311 nm - uzyskano szybkie ustępowanie wykwitów skórnych oraz złagodzenie objawów subiektywnych.

Wnioski. Liszaj płaski to zapalna dermatoza świądowa, często o przewlekłym przebiegu, która może negatywnie wpływać na jakość życia chorych. Opisywany przypadek sześcioletniego chłopca z rozpoznanym na podstawie obrazu klinicznego i histopatologicznego liszajem płaskim wskazuje na konieczność uwzględnienia tej choroby w trakcie diagnostyki różnicowej zmian grudkowych z towarzyszącym świądem $\mathrm{u}$ dzieci. Ponadto istotne jest zwrócenie uwagi na możliwość ciężkiego przebiegu choroby, wymagającego włączenia leczenia ogólnego.

Słowa kluczowe: liszaj płaski, dzieci, leczenie.

Key words: lichen planus, children, treatment.

\section{INTRODUCTION}

Lichen planus is an inflammatory dermatosis having a characteristic clinical and histopathological presentation. The disease may involve scalp and glabrous skin, mucosa and nail plates. The disease may have a chronic and recurrent character, and may last for many years. Eruptions are mono- or multifocal, appear simultaneously or in some time intervals, and their morphology is various and depends on the occupied area. Dermatological changes are described by the English acronym " $6 \mathrm{P}$ ", standing for planar, purple, polygonal, pruritic papules and plaques [1-3]. Presence of white and delicate Wickham striae on the surface of eruptions is characteristic. This presentation is a result of irregular hypertrophy of the granulous layer of the epidermis. The other characteristic attribute is the Koebner phenomenon associated with dissemination of linear papular eruptions in sites of skin injury during the active phase of the disease. There are several clinical varieties of the disease, presented in the table 1 along with information regarding the differential diagnostics [4]. In mucosa, eruptions have commonly the form of symmetrical papules forming patterns of nets or rings, as well as foci of atrophic or eroding character, possibly accompanied by pain that sometimes is intense. It was demonstrated that occupation of nail plates, manifested by longitudinal grooving, reduced thickness, coarseness, discolouration, exfoliation or onychomadesis, and subungual hyperkeratosis and development of pterygium, accounts for a significant reduction of the quality of life [5]. Disseminated or clustered perifollical papules with subsequent permanent scarring hair loss are observed on the scalp $[2,3]$.

Lichen planus is associated with the risk of some serious complications. Eroding form of the disease, involving mucosa and conjunctiva, may lead to scar formation, fibrosis and stenosis, and in the area of

\section{WPROWADZENIE}

Liszaj płaski to zapalna dermatoza świądowa o charakterystycznym obrazie klinicznym i histopatologicznym, która może zajmować skórę gładką, owłosioną, błony śluzowe oraz płytki paznokciowe. Choroba może mieć przewlekły, wieloletni i nawrotowy charakter. Wykwity są jedno- lub wieloogniskowe, pojawiają się jednocześnie lub w odstępach czasowych, a ich morfologia różni się w zależności od zajętej okolicy. Zmiany skórne określa wywodzący się z języka angielskiego akronim „6 $6 \mathrm{P}^{\prime \prime}$, który oznacza kolejno: planar (płasko-wyniosłe), purple (sinofioletowe), polygonal (wieloboczne), pruritic (swędzące), papules (grudki) oraz plaques (tarczki) [1-3]. Charakterystyczne jest występowanie na powierzchni zmian białej, delikatnej siateczki Wickhama, która jest skutkiem nieregularnego przerostu warstwy ziarnistej naskórka, a także objawu Koebnera, związanego z wysiewem w aktywnej fazie choroby linijnie układających się wykwitów grudkowych w miejscach urazu skóry. Wyróżnia się kilka odmian klinicznych choroby, które wraz z diagnostyką różnicową przedstawiono w tabeli 1 [4]. Na błonie śluzowej wykwity chorobowe najczęściej mają postać rozmieszczonych symetrycznie grudek, tworzących siateczkowate lub obrączkowate wzory, a także ognisk o charakterze zanikowym lub nadżerkowym, którym mogą towarzyszyć dolegliwości bólowe, niekiedy o znacznym nasileniu. Wykazano, że zajęcie płytek paznokciowych, objawiające się podłużnym pobruzdowaniem, ścieńczeniem, szorstkością, zmianą zabarwienia, złuszczaniem lub spełzaniem oraz hiperkeratozą podpaznokciową i występowaniem skrzydlika, przyczynia się do znacznego obniżenia jakości życia [5]. W obrębie skóry owłosionej głowy można obserwować rozsiane lub skupiające się grudki przymieszkowe z następczym trwałym łysieniem bliznowaciejącym $[2,3]$. 
genitals it may result in phimosis, and in eyes to sight disorders or even blindness [2]. Moreover, cases of squamous cell carcinoma of the skin and mucosa developing secondary to lichen planus, were reported [6].

Clinical presentation of the disease is sufficiently typical to make the diagnosis in majority of cases. In case of any doubts, histopathological examination, and sometimes also immunofluorescent examination of collected biopsy specimens are useful. Epidermal hyperplasia, vacuolar degeneration within the basal membrane, apoptotic Civatte bodies, and epidermal acanthosis characterized by a "saw-tooth" appearance of the rete ridges of the epidermis, as well as the lymphocytic-histiocytic inflammatory infiltration along the dermis-epidermis interface (interface dermatitis) suggest the diagnosis of lichen planus. A typical immunofluorescence presentation involves presence of antibody-containing colloid bodies, mostly with $\operatorname{IgM}$, IgA and IgG antibodies and elements of the complement C3c $[1,2,4,5,7]$.

Despite numerous studies, aetiopathogenesis of lichen planus, first described in 1869, remains un-
Liszaj płaski wiąże się z ryzykiem rozwoju poważnych powikłań. Postać nadżerkowa obejmująca błony śluzowe i spojówki może być przyczyną bliznowacenia, włóknienia oraz zwężeń, co w okolicy narządów płciowych powoduje powstanie stulejki, natomiast w obrębie narządu wzroku prowadzi do zaburzeń, a nawet całkowitej utraty widzenia [2]. Opisywane są ponadto przypadki rozwoju raka kolczystokomórkowego skóry i błon śluzowych na podłożu zmian w przebiegu liszaja płaskiego [6].

Obraz kliniczny choroby jest na tyle charakterystyczny, że w większości przypadków wystarcza do ustalenia rozpoznania. $W$ razie wątpliwości pomocne są wyniki badania histopatologicznego, a niekiedy badania immunofluorescencyjnego pobranych bioptatów. Przerost warstw naskórka, zwyrodnienie wodniczkowe w obrębie błony podstawnej, apoptotyczne ciałka Civatte'a, obraz „zębów piły” wynikający z obecności sopli naskórkowych, a także układający się wzdłuż granicy skórno-naskórkowej limfocytarno-histiocytarny naciek zapalny (tzw. interface dermatitis) świadczą o występowaniu liszaja płaskiego. Natomiast w typowym obrazie immunofluorescen-

Table I. Clinical forms of lichen planus and the differential diagnostics

\begin{tabular}{|c|c|}
\hline Form of lichen planus & Differential diagnostics \\
\hline $\begin{array}{l}\text { Hypertrophic lichen planus - clear acanthosis and hyperkeratosis in histopathological presentation. } \\
\text { Skin eruptions are in form of cohesive or hard papulas and plaques with a papillous or } \\
\text { hyperkeratotic surface. Lesions are often accompanied by itch }\end{array}$ & - Chronic lichen simplex \\
\hline $\begin{array}{l}\text { Athrophic lichen planus - rare. In histopathological presentation a dominating atrophy of the } \\
\text { epidermis and a moderately intensified lymphocytic infiltration. Oval-shaped, brown or purple } \\
\text { papulas are observed in this form, with atrophy visible in the centre }\end{array}$ & $\begin{array}{l}\text { - Erythema dyschromicum } \\
\text { perstans (ashy dermatosis) }\end{array}$ \\
\hline $\begin{array}{l}\text { Ulcerative lichen planus - most commonly developing on feet. Clinical presentation involves } \\
\text { ulcerations or erosions with sharp, raised undermined borders, accompanied by intensive pain. } \\
\text { Lesions may require surgical treatment }\end{array}$ & $\begin{array}{l}\text { - Chronic paronychia } \\
\text { - Infection of inter-toe spaces } \\
\text { caused by Gram-negative } \\
\text { bacteria } \\
\text { - Trophic ulcer }\end{array}$ \\
\hline $\begin{array}{l}\text { Pemphigoides lichen planus - lesions in form of blisters occur both within existing papulas and on } \\
\text { unchanged skin. The clinical, histopathological and immunofluoroscpic attributes of lichen planus } \\
\text { and bullous pemphigoid are present in this form }\end{array}$ & - Bullous pemphigoid \\
\hline $\begin{array}{l}\text { Pigmented lichen planus - spots and papules demonstrating various discolourations, from grey- } \\
\text { brown via purple to dark-brown, typically localised in intertriginous areas and bending sites of } \\
\text { extremities }\end{array}$ & $\begin{array}{l}\text { - Intertrigo } \\
\text { - Localized scleroderma }\end{array}$ \\
\hline $\begin{array}{l}\text { Erythrodermic lichen planus - very rare variety, characterised by experience of intense itch and } \\
\text { general weakness. Typical lichen lesions on the skin, blisters or erosions localised within foci of } \\
\text { erythrodermia }\end{array}$ & - Erythrodermia \\
\hline $\begin{array}{l}\text { Inverse lichen planus - poorly limited erythematous foci, papules, erosions and hyperpigmentation } \\
\text { spots localised within folds, flexural areas, armpits and groin are visible in this variety }\end{array}$ & $\begin{array}{l}\text { - Intertrigo } \\
\text { - Inverse psoriasis }\end{array}$ \\
\hline $\begin{array}{l}\text { Linear lichen planus - lineal lesions of various morphology, size and localisation, more commonly } \\
\text { occurring in children and adolescents }\end{array}$ & $\begin{array}{l}\text { - Lichen striatus } \\
\text { - Inflammatory linear verrucous } \\
\text { epidermal nevus (ILVEN) }\end{array}$ \\
\hline $\begin{array}{l}\text { Follicular lichen planus - in histopathological presentation there are perifollicular inflammatory } \\
\text { infiltrations and fibrosis, leading to destruction and scarification of follicles. Pathological eruptions } \\
\text { manifest as erythematous and hyperkeratotic perifollicular papulas. Scarrying alopecia is observed }\end{array}$ & $\begin{array}{l}\text { - CLE (cutaneous lupus } \\
\text { erythematosus) } \\
\text { - Folliculitis decalvans }\end{array}$ \\
\hline $\begin{array}{l}\text { Lichen actinicus - lesions of various morphology localised in areas exposed to sunlight, not always } \\
\text { accompanied by itch. More often develop in young people with dark complexion }\end{array}$ & $\begin{array}{l}\text { - Chloasma } \\
\text { - Polymorphic light eruption (PLE) }\end{array}$ \\
\hline Annular lichen planus - papulas dominate in the clinical presentation & - Granuloma annulare \\
\hline
\end{tabular}


clear. It was determined that the disease is a result of immune disorders caused by, among others, viral antigens, toxins, drugs, injuries, stress, as well as some unknown autoantigens. Those factors stimulate the cellular response with participation of cytotoxic T cells CD8+.

Lichen planus occurs in $0.5-2 \%$ of the general population, with a slight prevalence in females. The form occupying the oral mucosa also occurs more often in women $(60-75 \%)$ compared to men. Some cases of familial lichen planus were reported [3]. The median age of dermal form of the disease is 40 , and of mucosal - 50-60 years. For that reason lichen planus is considered a disease affecting middle-aged individuals [7].

Treatment of lichen planus is symptomatic, and selection of a therapeutic method depends on localisation and intensity of eruptions, as well as on the clinical form of the disease. Potent glucosteroids are considered the first line treatment, along with calcineurin inhibitors, such as tacrolimus and pi- cyjnym obserwuje się ciałka koloidowe zawierające przeciwciała w klasach głównie IgM oraz IgA i IgG oraz składowe dopełniacza C3c [1, 2, 4, 5, 7].

Etiopatogeneza liszaja płaskiego, po raz pierwszy opisanego w 1869 roku, pomimo wielu badań nadal nie została całkowicie wyjaśniona. Ustalono, że choroba wynika z zaburzeń immunologicznych, do których przyczyniają się między innymi antygeny wirusowe, toksyny, leki, urazy, stres, a także nieznane autoantygeny. Czynniki te prowadzą do stymulacji odpowiedzi typu komórkowego z udziałem cytotoksycznych limfocytów T CD8+.

Liszaj płaski dotyczy 0,5-2\% populacji ogólnej, z niewielką przewagą płci żeńskiej. Postać obejmująca błonę śluzową jamy ustnej również częściej dotyczy kobiet (60-75\%) niż mężczyzn. Opisano przypadki rodzinnego występowania liszaja płaskiego [3]. Mediana wieku wystąpienia postaci skórnej choroby wynosi 40 lat, a postaci obejmującej błony śluzowe 50-60 lat, dlatego liszaj płaski jest uznawany za chorobę osób w średnim wieku [7].

Tabela I. Odmiany kliniczne liszaja płaskiego i diagnostyka różnicowa

\begin{tabular}{|c|c|}
\hline Postać liszaja płaskiego & Diagnostyka różnicowa \\
\hline $\begin{array}{l}\text { Liszaj płaski przerostowy - w obrazie histopatologicznym wyraźna akantoza i hiperkeratoza. } \\
\text { Wykwity skórne występują w postaci spoistych lub twardych grudek i tarczek o brodawkującej lub } \\
\text { hiperkeratotycznej powierzchni. Zmianom często towarzyszy świąd }\end{array}$ & - Przewlekły liszaj zwykły \\
\hline $\begin{array}{l}\text { Liszaj płaski zanikowy - występuje rzadko. W obrazie histopatologicznym charakterystyczny jest } \\
\text { dominujący zanik naskórka i średnio nasilony naciek z limfocytów. W tej postaci obserwuje się } \\
\text { owalne grudki i tarczki barwy brązowej lub fioletowej z widocznym zanikiem w centrum }\end{array}$ & $\begin{array}{l}\text { - Erythema dyschromicum } \\
\text { perstans (ashy dermatosis) }\end{array}$ \\
\hline $\begin{array}{l}\text { Liszaj płaski wrzodziejący - najczęściej dotyczy stóp. W obrazie klinicznym obserwuje się } \\
\text { owrzodzenia lub nadżerki o ostrych, wałowatych brzegach, którym towarzyszą nasilone } \\
\text { dolegliwości bólowe. Zmiany niekiedy wymagają interwencji chirurgicznej }\end{array}$ & $\begin{array}{l}\text { - Przewlekła paronychia } \\
\text { - Zakażenie przestrzeni } \\
\text { międzypalcowych stóp } \\
\text { wywołane przez bakterie } \\
\text { Gram-ujemne } \\
\text { - Owrzodzenia troficzne }\end{array}$ \\
\hline $\begin{array}{l}\text { Liszaj płaski typu pemfigoid - zmiany chorobowe w postaci pęcherzy rozwijają się w obrębie } \\
\text { grudek oraz na skórze niezmienionej. W tej odmianie w obrazie klinicznym, histopatologicznym } \\
\text { i immunofluorescencyjnym występują cechy liszaja płaskiego i pemfigoidu pęcherzowego }\end{array}$ & - Pemfigoid pęcherzowy \\
\hline $\begin{array}{l}\text { Liszaj płaski barwnikowy - różnie przebarwione, od szarobrązowego przez fioletowe } \\
\text { do ciemnobrązowego, plamy i grudki, typowo lokalizujące się w okolicach wyprzeniowych } \\
\text { oraz w zgięciach kończyn }\end{array}$ & $\begin{array}{l}\text { - Wyprzenia } \\
\text { - Twardzina ograniczona }\end{array}$ \\
\hline $\begin{array}{l}\text { Liszaj płaski erytrodermiczny - odmiana występująca bardzo rzadko, charakteryzująca się } \\
\text { odczuwaniem nasilonego świądu i ogólnego osłabienia. Na skórze obserwuje się typowe zmiany } \\
\text { liszajowate, pęcherzowe lub nadżerkowe lokalizujące się w obrębie ognisk erytrodermii }\end{array}$ & - Erytrodermia \\
\hline $\begin{array}{l}\text { Liszaj płaski odwrócony - w tej odmianie widoczne są słabo odgraniczone ogniska rumieniowe, } \\
\text { grudki, nadżerki i plamy hiperpigmentacyjne zlokalizowane w obrębie fałdów, zgięć, pach, pachwin }\end{array}$ & $\begin{array}{l}\text { - Wyprzenia } \\
\text { - Łuszczyca odwrócona }\end{array}$ \\
\hline $\begin{array}{l}\text { Liszaj płaski linijny - linijnie układające się zmiany o różnej morfologii, wielkości i lokalizacji, częściej } \\
\text { występujące u dzieci i młodzieży }\end{array}$ & $\begin{array}{l}\text { - Liszaj linijny } \\
\text { - Zapalne linijne brodawkowate } \\
\text { znamię naskórkowe (ILVEN) }\end{array}$ \\
\hline $\begin{array}{l}\text { Liszaj płaski mieszkowy - w obrazie histopatologicznym obecne są okołomieszkowe nacieki } \\
\text { zapalne i włóknienie, prowadzące do destrukcji i bliznowacenia mieszków. Wykwity chorobowe } \\
\text { mają postać rumieniowych i hiperkeratotycznych grudek przymieszkowych. Stwierdza się łysienie } \\
\text { bliznowaciejące }\end{array}$ & $\begin{array}{l}\text { - Toczeń rumieniowaty skórny } \\
\text { (CLE) } \\
\text { - Wyłysiające zapalenie } \\
\text { mieszków włosowych }\end{array}$ \\
\hline $\begin{array}{l}\text { Lichen actinicus - zmiany o różnej morfologii lokalizują się w okolicach eksponowanych na } \\
\text { promieniowanie słoneczne, nie zawsze towarzyszy im świąd. Częściej pojawiają się u osób } \\
\text { młodych o ciemnym fototypie skóry }\end{array}$ & $\begin{array}{l}\text { - Ostuda } \\
\text { - Wielopostaciowe osutki } \\
\text { świetlne (PLE) }\end{array}$ \\
\hline Liszaj płaski obrączkowaty - w obrazie klinicznym przeważają grudki o układzie obrączkowatym & - Ziarniniak obrączkowaty \\
\hline
\end{tabular}


mecrolimus. Also UVA, UVB $311 \mathrm{~nm}$ phototherapy is recommended. PUVA-therapy is recommended for patients over the age of 12 years. In refractory, severe or rapidly progressing cases, introduction of systemic treatment with glucocorticosteroids, dapsone, acitretin, cyclosporine, hydroxychloroquine, azathioprine, mycophenolate mofetil is recommended, and according to single reports also metronidazole or griseofulvin may be used $[1,2,4,7,8]$.

\section{OBJECTIVE}

This paper presents a case of a male child with confirmed disseminated lichen planus and offers a discussion of this dermatosis rarely occurring in paediatric patients.

\section{CASE REPORT}

A 6-year old boy was admitted to the Department of Dermatology, Venereology and Paediatric Dermatology of Medical University in Lublin, because of gradually developing and persisting for about a month papular eruptions accompanied by intese itch, sleep disorders and some significant difficulties in everyday function of the whole family of the patient. The boy top scored the experienced itch in the VAS (Visual Analogue Scale), which corresponded to 9-10 points in the 10-point NRS (Numeric Rating Scale). A strong urge to scratch skin was notable. Physical examination demonstrated no other abnormalities. Examination of medical history revealed atopic dermatitis in early childhood, currently in remission. The family history for chronic diseases was negative. The patient was vaccinated according to the valid schedule. The boy was not ill in preceding 3 months, used no medications, nor was injured. Parents observed periodical irritation, reduction of mood and reluctance in contacts with peers.

At the admission, there were numerous, disseminated, polygon and shiny papules covered with white Wickham striae, locally coalesce into into larger eruptions, some linear erosions and excoriations covered with crusts on the skin of the trunk, extremities and genital area. A positive Koebner phenomenon was observed (figs. 1, 2). Eruptions were accompanied with highly intense itch. The scalp, nail plates and oral mucosa were not changed. Laboratory tests, including viral, demonstrated no abnormalities. A specimen was collected from the pathologically changed skin on the buttock, for histopathological examination. Based on the observation of increased thickness of the granulous layer, necrosis of cells in the basal membrane, presence of colloid bodies, acanthosis of epidermis resembling saw teeth, and an abundant
Leczenie liszaja płaskiego ma charakter objawowy, a wybór metody zależy od umiejscowienia oraz nasilenia wykwitów, a także postaci klinicznej choroby. Lekami pierwszego wyboru są preparaty glikosteroidowe o dużej sile działania, a także inhibitory kalcyneuryny, takie jak takrolimus i pimekrolimus. Ponadto wysoką skutecznością cechuje się fototerapia UVA, UVB $311 \mathrm{~nm}$ oraz zalecana u pacjentów powyżej 12 . roku życia PUVA-terapia. W przypadkach opornych, o ciężkim lub szybko postępującym przebiegu wskazane jest wdrożenie leczenia ogólnego z użyciem glikokortykosteroidów, dapsonu, acytretyny, cyklosporyny, hydroksychlorochiny, azatiopryny, mykofenolanu mofetylu, a według pojedynczych doniesien także metronidazolu lub gryzeofulwiny $[1,2,4,7,8]$.

\section{CEL PRACY}

Celem pracy jest przedstawienie przypadku chłopca z rozpoznaniem liszaja płaskiego wysiewnego oraz dyskusja na temat tej rzadko występującej $\mathrm{u}$ dzieci dermatozy.

\section{OPIS PRZYPADKU}

Sześcioletni chłopiec został przyjęty do Kliniki Dermatologii, Wenerologii i Dermatologii Dziecięcej w Lublinie z powodu stopniowo pojawiających się i utrzymujących od około miesiąca wykwitów grudkowych, którym towarzyszył intensywny świąd, zaburzenia snu oraz istotne utrudnienie w codziennym funkcjonowaniu całej rodziny pacjenta. Na podstawie VAS (Visual Analogue Scale) nasilenie odczuwanego świądu chłopiec ocenił jako maksymalne, co odpowiadało 9-10 punktom w 10-punktowej numerycznej skali szacunkowej NRS (Numeric Rating Scale). Uwage zwracała silna potrzeba drapania skóry. W badaniu fizykalnym nie wykazano innych nieprawidłowości. W wywiadzie osobniczym stwierdzono występowanie u chłopca we wczesnym dzieciństwie atopowego zapalenia skóry, obecnie w fazie remisji. Wywiad rodzinny w kierunku chorób przewlekłych był ujemny. Pacjent był szczepiony zgodnie $\mathrm{z}$ obowiązującym kalendarzem. W czasie ostatnich 3 miesięcy chłopiec nie chorował, nie przyjmował żadnych leków, nie doznał urazu. Rodzice obserwowali okresowo występujące u niego rozdrażnienie, obniżenie nastroju i niechęć do nawiązywania kontaktu z rówieśnikami.

W chwili przyjęcia do Kliniki Dermatologii na skórze tułowia, kończyn i w okolicy narządów płciowych obserwowano liczne, rozsiane, wieloboczne, połyskujące grudki pokryte białą siateczką Wickhama, miejscami zlewające się w większe wykwity, a także linijne nadżerki i przeczosy pokryte strupami. Stwierdzono dodatni objaw Koebnera (ryc. 1, 2). 
lymphocytic infiltration on the, a preliminary diagnosis of lichen planus was confirmed.

The treatment involved UVB 311nm phototherapy (three times a week) and systemic glucocorticosteroid therapy (prednisone $1 \mathrm{mg} / \mathrm{kg}$ b.w. a day, p.o., with downtitration of the dose), antihistaminics (clemastine syrup), and topical steroid products (hydrocorisone and mometasone ointment), resulting in rapid local improvement of the clinical status (figs. 3, 4), alleviation of itch, disappearance of sleep disorders and return of activity in the group of peers.

\section{DISCUSSION}

With 2 to $3 \%$ of all diagnosed cases of the disease, lichen planus is rare in the paediatric population [8]. In Indian children the morbidity of lichen planus is estimated at $11-19 \%$ of all patients. Studies indicate existence of a correlation between development of
Wykwitom towarzyszył świąd o bardzo dużym nasileniu. Owłosiona skóra głowy, płytki paznokciowe oraz błona śluzowa jamy ustnej były niezmienione. W wykonanych w trakcie hospitalizacji badaniach laboratoryjnych, $\mathrm{w}$ tym wirusologicznych, nie odnotowano odchyleń od normy. Ze zmienionej chorobowo skóry pośladka pobrano wycinek do badania histopatologicznego. Na podstawie pogrubienia warstwy ziarnistej, martwicy komórek warstwy podstawnej, obecności ciałek koloidowych, wpukleń międzybrodawkowych typu "zębów piły” oraz obfitego nacieku limfocytarnego na granicy skórno-naskórkowej potwierdzono wstępne rozpoznanie kliniczne liszaja płaskiego.

W leczeniu zastosowano zabiegi fototerapii UVB $311 \mathrm{~nm}$ (3 razy w tygodniu) i glikokortykosteroidoterapię ogólną (prednizon $1 \mathrm{mg} / \mathrm{kg}$ m.c./dobę doustnie ze stopniową redukcją dawki), leki przeciwhistaminowe (klemastynę w syropie) oraz miejscowe preparaty glikokortykosteroidowe (hydrokortyzon
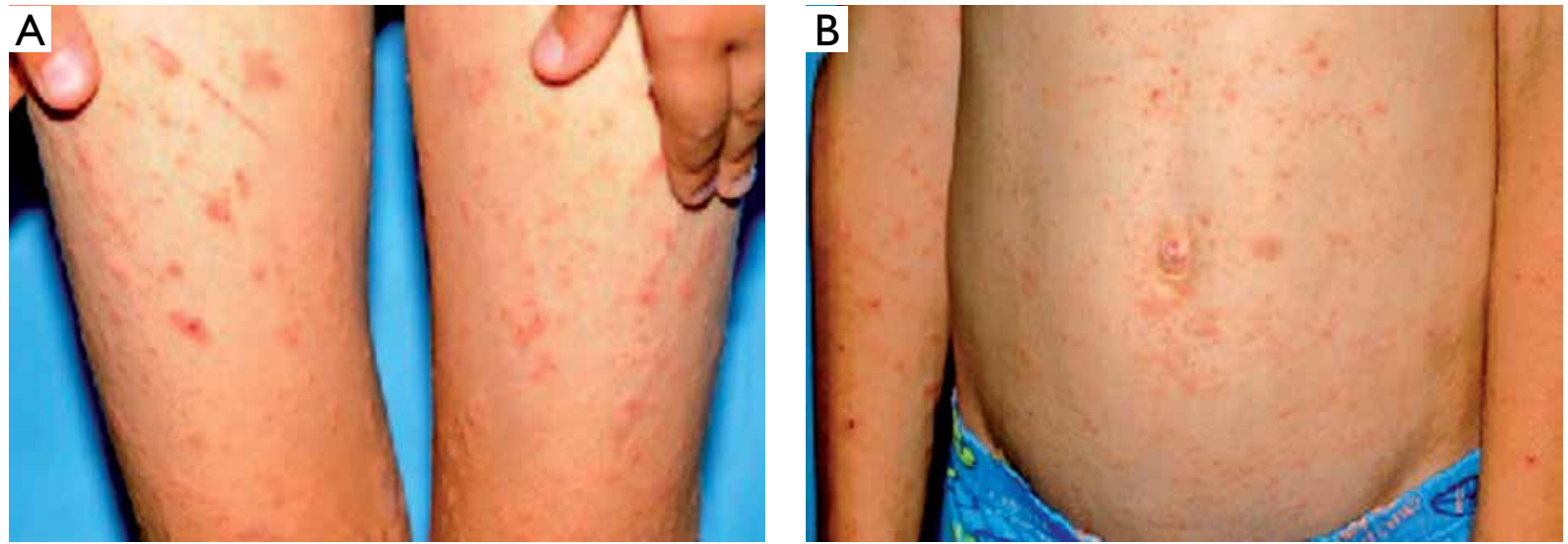

Figure I. Numerous, polygonic papulas and erosions present at the time of admission. Positive Koebner phenomenon Rycina I. Liczne, wieloboczne grudki oraz nadżerki obecne w chwili przyjęcia do szpitala na skórze tułowia i kończyn. Objaw Koebnera dodatni
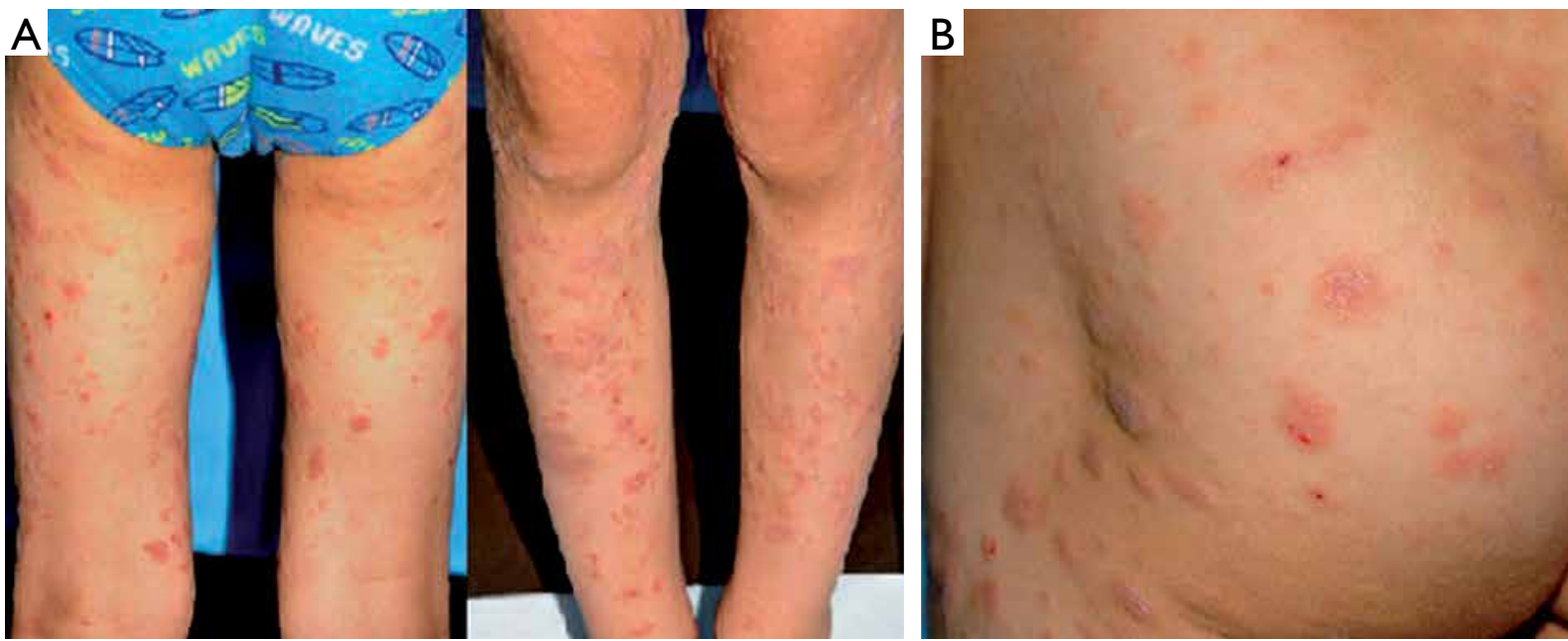

Figure 2. Skin lesions on lower extremities and buttocks

Rycina 2. Zmiany skórne na kończynach dolnych i pośladkach 

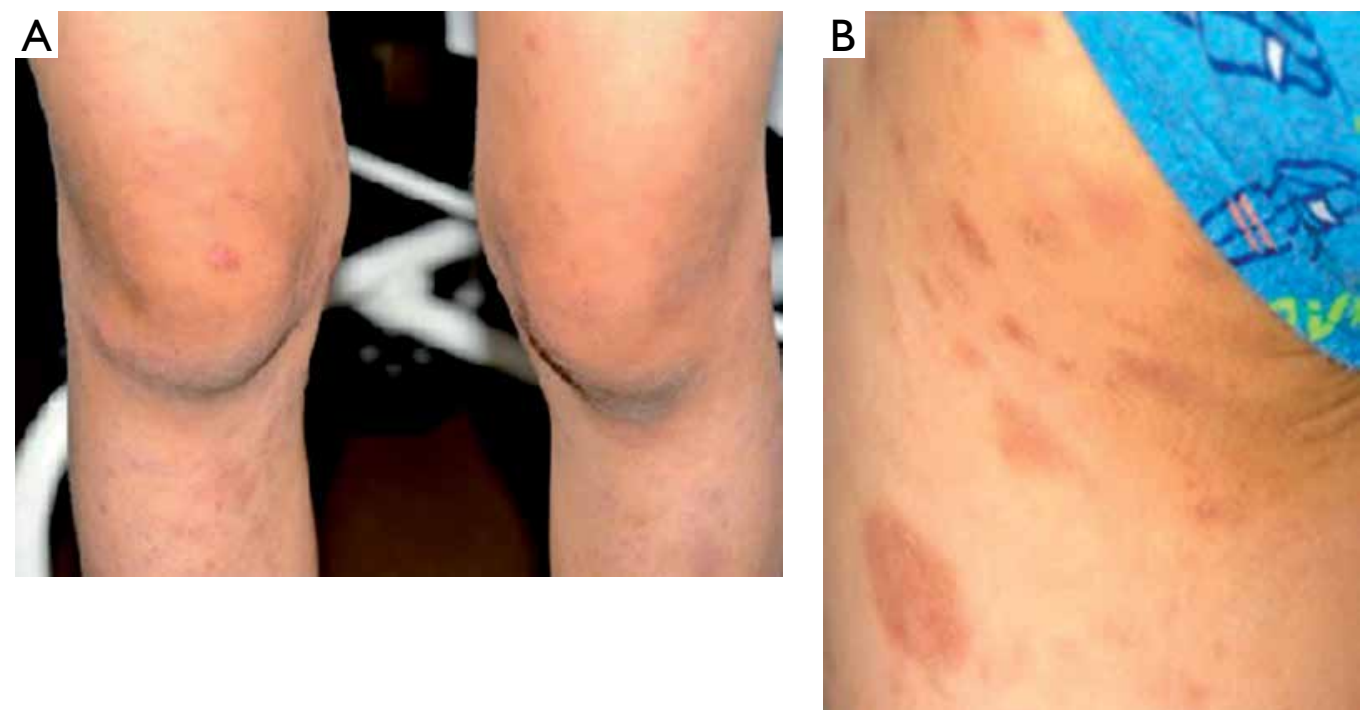

Figure 3. Presentation of skin lesions 15 days after introduction of treatment. Notable paler and more flat eruptions with a tendency to post-inflammatory hyperpigmentation and absence of erosions

Rycina 3. Obraz zmian skórnych po I 5 dniach od rozpoczęcia leczenia. Zwraca uwagę zblednięcie i spłaszczenie wykwitów z tendencją do tworzenia hiperpigmentacji pozapalnych oraz brak nadżerek
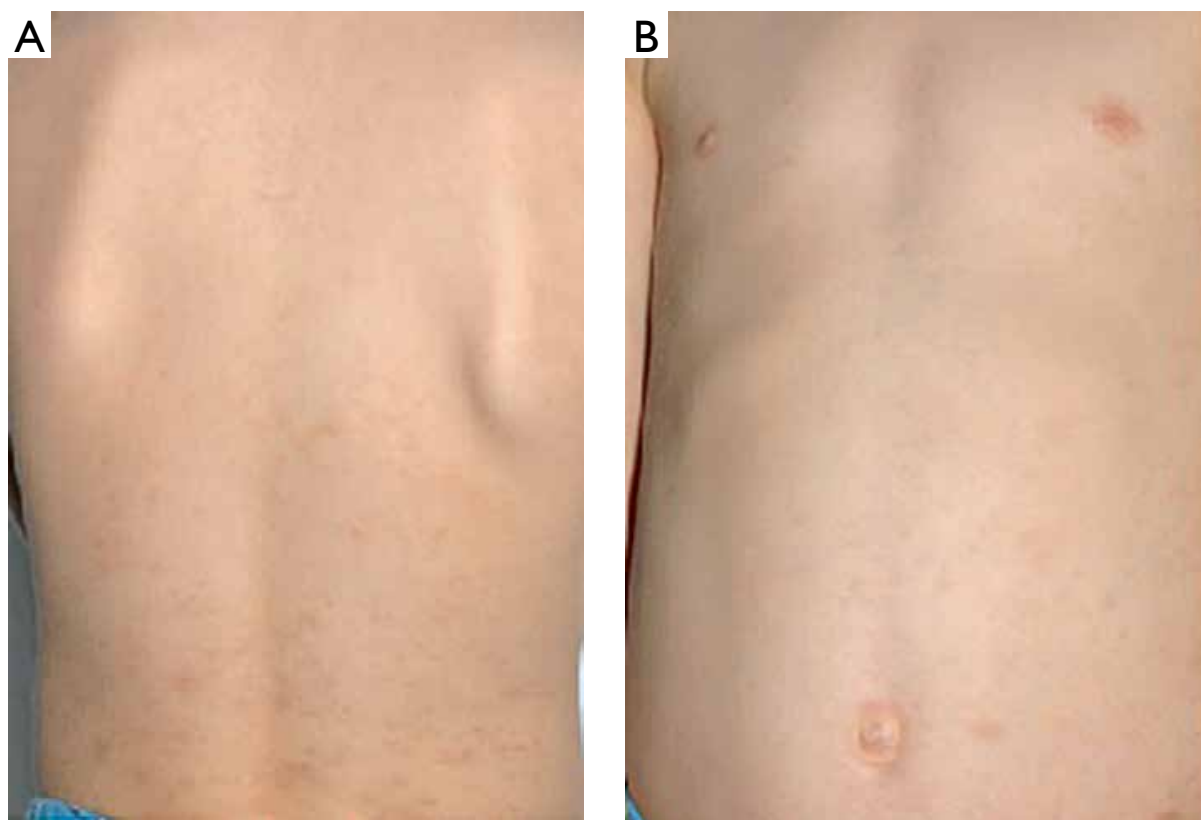

Figure 4. Presentation of skin lesions on the trunk 15 days after introduction of treatment. Visible discrete post-inflammatory discolourations

Rycina 4. Zmiany skórne na tułowiu po I 5 dniach od rozpoczęcia leczenia. Widoczne dyskretne przebarwienia pozapalne

lichen planus and presence of infective factors, mostly viral ones [9]. The association between hepatitis $\mathrm{C}$ virus (HCV) infection and lichen planus found in adults has not been confirmed in children [10]. Genetic, environmental factors, and drugs used, particularly NSAIDs, are suspected to play a role in aetiopathogenesis of the disease $[10,11]$. A possible autoimmune background is suggested by coexistence of lichen planus with vitiligo, alopecia areata and localized scleroderma [11, 12]. Based i mometazon w maści), uzyskując szybką miejscową poprawę kliniczną (ryc. 3, 4), złagodzenie świądu, ustąpienie zaburzeń snu, a także chęć do aktywności w grupie rówieśniczej.

\section{OMÓWIENIE}

Liszaj płaski w populacji dziecięcej występuje rzadko, jedynie w 2-3\% wszystkich rozpoznanych przypadków choroby [8]. Odsetek przypadków li- 
on case reports of family occurrence of the disease, it appears that in those patients the age of onset is earlier, the course of the disease is more severe and with the involvement of a larger area of the skin, the prognosis is worse, and the recurrence is more frequent compared to cases of sporadic disease [13]. Patients with a positive family history more often present erosive, hypertrophic and linear forms of the disease [14]. Probably the disease is inherited in the dominating autosomal manner, with a significant role of HLA-B7 and -DR10 antigens [10]. A lower percentage of cases in children compared to adults may be due to more systematic dental care, less frequent occurrence of autoimmune diseases, lower exposure to drugs and other environmental factors that probably play a role in the pathogenesis of lichen planus [15]. The similarity of the disease in children and adults consists in the appearance of the same clinical forms, a good response to treatment and a favourable prognosis $[15,16]$.

The incidence of the disease in both sexes in the paediatric population is similar, with a slight predominance of boys, presumably as a result of more frequent injuries during physical activity, compared to girls $[11,17]$. In majority of children first symptoms of lichen planus appear between the age of 5 and 9 years. The youngest patient with confirmed diagnosis was 3 month old, and the earliest case of suspected lichen planus occurred in a 2 week old neonate $[15,18-21]$. Typical duration of the disease is estimated at 8 to 15 months. Lesions disappear spontaneously, leaving post-inflammatory discolorations persisting for several months or even years. Discolorations are more clearly visible in children with dark complexion, which constitutes a significant cosmetic defect $[17,22]$. Treatment is able to reduce the duration of dermatosis down to 1-6 months [10, 19, 20].

Most commonly primary eruptions appear in the area of wrists and ankles, gradually spreading to other parts of the skin $[11,15,23]$. The classic form is regarded dominating in the paediatric population, followed by disseminated, hypertrophic and linear forms [10, 17, 23]. The Koebner phenomenon characteristic for lichen planus is usually present in children, even in $73.8 \%$ of observed patients [16]. Mucosal lesions occur in $13.7 \%$ to $30 \%$ of paediatric cases [23]. For comparison, they are present in $60 \%$ to $70 \%$ of adult patients [17]. Their clinical presentation is similar as in adults, but they response to treatment better and the associated prognosis is more favourable [15, 24-26]. Eruptions on palms, soles, genitals and oral mucosa frequently cause no subjective symptoms [11]. It seems that the percentage of children with nail plates occupied by the disease, estimated at $2.6 \%$ to $19 \%$, is significantly underestimated. That may be a result of less common exami- szaja płaskiego wśród dzieci indyjskich szacuje się na 11-19\% wszystkich chorych. Wyniki badań wskazują na istnienie zależności między rozwojem liszaja płaskiego a występowaniem czynników infekcyjnych, głównie wirusowych [9]. Udowodniony związek zakażenia wirusem zapalenia wątroby typu C (HCV) $\mathrm{z}$ wystąpieniem liszaja płaskiego $\mathrm{u}$ dorosłych nie znalazł potwierdzenia u dzieci [10]. Podejrzewa się, że wpływ na rozwój choroby i znaczenie w jej etiopatogenezie mają czynniki genetyczne, środowiskowe oraz leki, zwłaszcza z grupy niesteroidowych leków przeciwzapalnych $[10,11]$. Na możliwe tło autoimmunologiczne wskazuje współistnienie liszaja płaskiego $\mathrm{z}$ bielactwem, łysieniem plackowatym lub twardziną ograniczoną [11, 12]. Z opisów przypadków rodzinnego występowania choroby wynika, że u takich pacjentów wiek zachorowania jest wcześniejszy, przebieg choroby cięższy, z zajęciem większej powierzchni skóry, rokowanie gorsze, a nawroty częstsze w porównaniu z przypadkami sporadycznego występowania choroby [13]. U pacjentów z dodatnim wywiadem rodzinnym częściej występują odmiany nadżerkowa, przerostowa oraz linijna [14]. Przypuszczalnie dziedziczenie ma charakter autosomalny dominujący, z istotną rolą antygenów HLA-B7 oraz -DR10 [10]. Niższy odsetek zachorowań $\mathrm{u}$ dzieci w porównaniu z dorosłymi być może wynika z bardziej systematycznej opieki stomatologicznej, rzadszego występowania u nich chorób autoimmunologicznych, mniejszej ekspozycji na leki i inne czynniki środowiskowe, które prawdopodobnie odgrywają rolę w patogenezie liszaja płaskiego [15]. Podobieństwo choroby u dzieci i dorosłych polega na występowaniu tych samych postaci klinicznych, dobrej odpowiedzi na leczenie oraz korzystnym rokowaniu $[15,16]$.

Częstość występowania choroby u obu płci w populacji pediatrycznej jest zbliżona, z nieznaczną przewagą chłopców, przypuszczalnie wskutek częstszego w porównaniu z dziewczętami występowania u nich urazów w trakcie aktywności fizycznej $[11,17]$. U większości dzieci pierwsze objawy liszaja płaskiego pojawiają się pomiędzy 5. a 9. rokiem życia. Najmłodszy pacjent z potwierdzonym rozpoznaniem choroby miał 3 miesiące, natomiast najwcześniejszy podejrzewany o liszaja płaskiego przypadek dotyczył 2-tygodniowego noworodka [15, 18-21]. Czas trwania choroby o charakterystycznym przebiegu ocenia się na 8-15 miesięcy. Zmiany ustępują samoistnie $\mathrm{z}$ pozostawieniem utrzymujących się przez kilka miesięcy, a nawet lat przebarwień pozapalnych, znacznie wyraźniejszych u dzieci z wyższymi fototypami skóry. Stanowi istotny defekt kosmetyczny $[17,22]$. Leczenie skraca czas trwania dermatozy do 1-6 miesięcy [10, 19, 20].

Najczęściej wykwity pierwotnie pojawiają się w okolicy nadgarstków i kostek, stopniowo obejmu- 
nation of nails performed in children. Tosti et al. [27] divided subungual lesions into three groups: typical changes, trachyonychia and idiopathic atrophy of the nails. Typical lesions are: longitudinal grooving, reduced thickness, coarseness, discolouration, exfoliation or onychomadesis, subungual hyperkeratosis and pterygium. Trachyonychia, or paediatric dystrophy of twenty nails, is characterised by longitudinal grooving of plates and their excessive coarseness. And idiopathic atrophy of the nails is a sudden, rapidly progressing, asymptomatic atrophy of several or all nail plates, with or without an accompanying pterygium and areas of scarring. Authors of the paper emphasized that trachyonychia and idiopathic atrophy of the nails are not present in adults with lichen planus $[11,15,27]$.

The main purpose of treatment is to achieve complete disappearance of symptoms $[15,28]$. To reduce itch that accompanies dermal-mucosal eruptions and having a negative impact on patients' quality of life, treatment should be introduced as early as possible [15]. Medium to high potency topical glucosteroid products remain the first line treatment. They are used in the form of ointment, cream, gel, and also as intrafocal injections. Parents should be informed about a possible harmful effect of those drugs applied on large area of the skin, and on intensification of topically applied glucosteroid products by occlusive dressing. It is agreed that time necessary to alleviate itch is approximately 3 weeks, and skin eruptions are flattened within approx. 6 weeks of topical treatment [15]. Calcineurin inhibitors are characterised by a more favourable safety profile, compared to topically administered glucosteroids. Some reports confirm their therapeutic effectiveness in relation to skin eruptions and mucosal lesions in children with lichen planus $[10,15,17,28]$. The therapy of mucosal lesions is recommended if eruptions cause subjective symptoms, and also in case of development of erosions or ulcerations. Asymptomatic lesions do not require any additional pharamacotherapy [15, 24, 26]. Phototherapy with UVA, narrow-spectrum UVB and the PUVA-therapy in children over 12 years of age, are considered valuable therapeutic methods. Systemic treatment is required in patients with severe and progressing disease, and also those resistant to topical treatments. Among drugs associated with reported therapeutic success there are: glucocorticosteroids, dapsone, acitretin, metothrexate, metronidazole, cyclosporin, griseofulvin, phenytoin, sulfasalazine, levamisol, talidomide and mycophenolate mofetil $[15,17-19,28]$. Undoubtedly, selection of the therapeutic method is affected by intensity of pathological changes, possible contraindications, and experience of a doctor $[10,15,21,28]$. jąc pozostałe partie skóry [11, 15, 23]. Za dominującą $\mathrm{w}$ populacji pediatrycznej uznaje się postać klasyczną, następnie odmianę wysiewną, przerostową i linijną [10, 17, 23]. Charakterystyczny dla liszaja płaskiego objaw Koebnera u dzieci występuje często, nawet $\mathrm{u} 73,8 \%$ poddanych obserwacjom pacjentów [16]. Zmiany na błonach śluzowych dotyczą 13,7-30\% przypadków dziecięcych [23], dla porównania u dorosłych odnotowuje się je u ok. 60-70\% pacjentów [17]. Mają one podobne cechy kliniczne jak u dorosłych, ale łatwiej poddają się leczeniu i lepiej rokują [15, 24-26]. Wykwity na skórze dłoni, podeszew, narządów płciowych i błonie śluzowej jamy ustnej u dzieci często nie dają objawów subiektywnych [11]. Wydaje się, że odsetek dzieci z zajętymi przez proces chorobowy płytkami paznokciowymi szacowany na 2,6-19\% jest znacznie zaniżony, co może wynikać z rzadszego niż u dorosłych pacjentów wykonywania badań potwierdzających zajęcie aparatu paznokciowego. Tosti i wsp. [27] podzielili zmiany paznokciowe u dzieci na trzy grupy, wyróżniając odpowiednio zmiany typowe, trachyonychię i idiopatyczny zanik paznokci. Do charakterystycznych zmian zaliczono: podłużne pobruzdowanie, ścieńczenie, szorstkość, zmianę zabarwienia, złuszczanie lub spełzanie płytek paznokciowych, hiperkeratozę podpaznokciową oraz skrzydlik, czyli pterygium. Dla trachyonychii, czyli dziecięcej dystrofii dwudziestu paznokci, charakterystyczne są podłużne pobruzdowanie płytek paznokci oraz ich nadmierna szorstkość. Z kolei idiopatyczny zanik paznokci to nagły, szybko postępujący, asymptomatyczny zanik kilku lub wszystkich płytek paznokciowych, któremu może towarzyszyć skrzydlik i obszary bliznowacenia. Jednocześnie autorzy publikacji podkreślili, że trachyonychia oraz idiopatyczny zanik paznokci nie występują u osób dorosłych z liszajem płaskim [11, 15, 27].

Głównym celem leczenia jest uzyskanie całkowitego ustąpienia objawów choroby $[15,28]$. Aby ograniczyć towarzyszący wykwitom skórno-śluzówkowym świąd, negatywnie wpływający na jakość życia chorych, zaleca się jak najszybsze wdrożenie odpowiedniego leczenia [15]. Lekami pierwszego wyboru są miejscowe preparaty glikosteroidowe o średniej i dużej sile działania, stosowane w postaci maści, kremu, żelu i iniekcji doogniskowych. Rodzice powinni uzyskać informację o możliwej szkodliwości stosowania leków na dużą powierzchnię skóry oraz nasileniu działania aplikowanych miejscowo preparatów glikosteroidowych przez opatrunek okluzyjny. Uznaje się, że czas wymagany do zmniejszenia dolegliwości świądowych wynosi ok. 3 tygodni, natomiast wykwity skórne ulegają spłaszczeniu po ok. 6 tygodniach leczenia miejscowego [15]. Inhibitory kalcyneuryny cechuje większy profil bezpieczeństwa $\mathrm{w}$ porównaniu $\mathrm{z}$ miejscowo aplikowanymi glikosteroidami. Istnieją doniesienia, 


\section{CONCLUSIONS}

Lichen planus is an immunologically-mediated inflammatory dermatosis associated with itch that may be intense. It was demonstrated that early diagnosis and effective treatment reduce duration of the disease and improve patients' quality of life. Considering the fact that lichen planus is rare in children, the described case of a six-year-old boy who was diagnosed with the dermatosis based on the correlation of the clinical and histopathological presentation, it is necessary to include lichen planus in the differential diagnosis of papular changes with associated pruritus in children. It is also important to consider a systemic treatment in case of severe course of the disease.

\section{CONFLICT OF INTEREST}

The authors declare no conflict of interest. które potwierdzają ich skuteczność terapeutyczną w stosunku do wykwitów skórnych oraz wykwitów na błonie śluzowej u dzieci z liszajem płaskim [10, $15,17,28]$. Terapia zmian na błonach śluzowych jest zalecana, gdy wykwity wywołują objawy subiektywne, a także w przypadku występowania nadżerek lub owrzodzeń. Pozostałe, asymptomatyczne zmiany nie wymagają dodatkowego postępowania farmakologicznego $[15,24,26]$. Światłolecznictwo z zastosowaniem promieniowania UVA, wąskopasmowego UVB oraz PUVA-terapia u dzieci powyżej 12. roku życia są uznawane za cenną metodę leczenia. Leczenie ogólne przeznaczone jest dla pacjentów z ciężkim, postępującym przebiegiem choroby i opornych na terapię miejscową. Do leków, po których zastosowaniu odnotowano sukces terapeutyczny, należą: glikokortykosteroidy, dapson, acytretyna, metotreksat, metronidazol, cyklosporyna, gryzeofulwina, fenytoina, sulfasalazyna, lewamizol, talidomid oraz mykofenolan mofetylu $[15,17-19,28]$. Niewątpliwie na wybór metody leczenia wpływają nasilenie zmian chorobowych, ewentualne przeciwwskazania do rozpoczęcia terapii danym lekiem, a także doświadczenie lekarza [10, 15, 21, 28].

\section{WNIOSKI}

Liszaj płaski to dermatoza zapalna mediowana immunologicznie, przebiegająca ze świądem, niekiedy o dużym nasileniu. Wykazano, że wczesne rozpoznanie i skuteczne leczenie skracają czas trwania choroby i wpływają na poprawę jakości życia pacjentów. Ze względu na fakt, że liszaj płaski w populacji pediatrycznej występuje rzadko, opisywany przypadek sześcioletniego chłopca, u którego na podstawie korelacji obrazu klinicznego i histopatologicznego rozpoznano tę dermatozę, wskazuje na konieczność jej uwzględnienia $w$ diagnostyce różnicowej zmian grudkowych z towarzyszącym świądem u dzieci. Ponadto istotne jest zwrócenie uwagi na możliwość ciężkiego przebiegu choroby, wymagającego włączenia leczenia ogólnego.

\section{KONFLIKT INTERESÓW}

Autorzy nie zgłaszają konfliktu interesów.

\section{References \\ Piśmiennictwo}

1. Usatine R.P., Tinitigan M.: Diagnosis and treatment of lichen planus. Am Fam Physician 2011, 84, 53-60.

2. Le Cleach L., Chosidow O.: Clinical practice. Lichen planus. N Engl J Med 2012, 366, 723-732.

3. Berger T.G.: Lichen planus. JAMA Dermatol 2015, 151, 356.

4. Wagner G., Rose C., Sachse M.M.: Clinical variants of lichen planus. J Dtsch Dermatol Ges 2013, 11, 309-319.

5. Krasowska D.: Liszaj płaski. Nowa Medycyna 2000, 11.

6. Lodi G., Scully C., Carrozzo M., Griffiths M., Sugerman P.B., Thongprasom K.: Current controversies in oral lichen planus: report of an international consensus meeting. Part 2. Clinical management and malignant transformation. Oral Surg Oral Med Oral Pathol Oral Radiol Endod 2005, 100, 164-178. 
7. Goldstein B.G., Goldstein A.O., Mostow E.: Lichen planus. UpToDate. Available at: https://www.uptodate.com/contents/ lichen-planus\#H16.

8. Paller A.S., Mancini A.J.: Papulosquamous and related disorders. [In:] Hurwitz Clinical Pediatric Dermatology: a Textbook of Skin Disorders of Childhood and Adolescence. A.S. Paller, A.J. Mancini (eds.), Elsevier, New York 2016, 73-94.

9. Lodi G., Scully C., Carrozzo M., Griffiths M., Sugerman P.B., Thongprasom K.: Current controversies in oral lichen planus: report of an international consensus meeting. Part 1. Viral infections and etiopathogenesis. Oral Surg Oral Med Oral Pathol Oral Radiol Endod 2005, 100, 40-51.

10. Lee S.X., Tay Y.K.: Lichen planus in children. In: Pediatric Skin of Color. N.B. Silverberg, C. Durán-McKinster, Y.K. Tay (eds). Springer, New York 2015, 295-301.

11. Kambil S.M., Ravikiran S.P., Jaiswal A.K., Anupama Y.G., Madan Mohan N.T., Reddy P.K.: Lichen planus in children: a retrospective study in 76 patients at a tertiary care center in South India. Indian J Paediatr Dermatol 2017, 18, 209-213.

12. Balasubramaniam P., Ogboli M., Moss C.: Lichen planus in children: review of 26 cases. Clin Exp Dermatol $2008,33,457-459$.

13. Singal A.: Familial mucosal lichen planus in three successive generations. Int J Dermatol 2005, 44, 81-82.

14. Pedraz J., Conde-Taboada A., Campos-Muñoz L., López-Bran E.: Familial eruptive generalized lichen planus in a pediatric patient. J Dermatol 2010, 37, 910-912.

15. Malathi M., Thappa D.M.: Management of childhood lichen planus. Nepal J Dermatol Venereol Leprol 2014, 12, 1-6.

16. Kumar A., Mendiratta V., Agarwal S., Chander R., Sanke S.: Childhood lichen planus: a series of 42 patients. Indian J Paediatr Dermatol 2018, 19, 116-119.

17. Pandhi D., Singal A., Bhattacharya S.N.: Lichen planus in childhood: a series of 316 patients. Pediatr Dermatol $2014,31,59-67$.

18. Kanwar A.J., De D.: Lichen planus in children. Indian J Dermatol Venereol Leprol 2010, 76, 366-372.

19. Sharma R., Maheshwari V.: Childhood lichen planus: a report of fifty cases. Pediatr Dermatol 1999, 16, $345-348$.

20. Nanda A., Al-Ajmi H.S., Al-Sabah H., Al-Hasawi F., Alsaleh Q.A.: Childhood lichen planus: a report of 23 cases. Pediatr Dermatol 2001, 18, 1-4.

21. Pusey W.A.: Lichen planus in an infant less than six months old. Arch Derm Syphilol 1929, 19, 671-672.

22. Kumar V., Garg B.R., Baruah M.C., Vasireddi S.S.: Childhood lichen planus. J Dermatol 1993, 20, $175-177$.

23. Kambil S.M.: Clinico-epidemiological study of childhood lichen planus at a tertiary care centre in South India. Int J Res Dermatol 2018, 4, 346-348.

24. Alam F., Hamburger J.: Oral mucosal lichen planus in children. Int J Paediatr Dent 2001, 11, $209-214$.

25. Shekhar M.G., Sudhakar R., Shahul M., Tenny J., Ravikanth M., Manikyakumar N.: Oral lichen planus in childhood: a rare case report. Dermatol Online J 2010, 16, 9.

26. Laceijendecker R., Van Joost T., Tank B., Oranje A.P., Neumann H.A.: Oral lichen planus in childhood. Pediatr Dermatol 2005, 22, 299-304.

27. Tosti A., Piraccini B.M., Cambiaghi S., Jorizzo M.: Nail lichen planus in children: clinical features, response to treatment, and long-term follow-up. Arch Dermatol 2001, 137, 1027-1032.

28. Nischal U., Kharkar V.: Different treatment modalities in the treatment of childhood lichen planus. Indian J Drugs Dermatol 2016, 2, 87-92.

Received: 26.10 .2018

Accepted: 15.01 .2019

Otrzymano: 26.10 .2018 r.

Zaakceptowano: 15.01.2019 r.

How to cite this article

Szczepanik-Kułak P., Bartosińska J., Wawrzycki B., Krasowska D.: Eruptive lichen planus in a six-year-old boy. Dermatology Rev/Przegl Dermatol 2019, 106, 310-320. DOI: https://doi.org/10.5114/dr.2019.86914. 